Open Access

\title{
Polyethylene glycol-mediated fusion of herpes simplex type 1 virions with the plasma membrane of cells that support endocytic entry
}

Erik B. Walker ${ }^{1 \dagger}$, Suzanne M. Pritchard ${ }^{1 \dagger}$, Cristina W. Cunha ${ }^{1}$, Hector C. Aguilar ${ }^{1,2}$ and Anthony V. Nicola ${ }^{1,2^{*}}$

\begin{abstract}
Background: Mouse B78 cells and Chinese hamster ovary $(\mathrm{CHO})$ cells are important to the study of HSV-1 entry because both are resistant to infection at the level of viral entry. When provided with a gD-receptor such as nectin-1, these cells support HSV-1 entry by an endocytosis pathway. Treating some viruses bound to cells with the fusogen polyethylene glycol (PEG) mediates viral fusion with the cell surface but is insufficient to rescue viral entry. It is unclear whether PEG-mediated fusion of HSV with the plasma membrane of B78 or CHO cells results in successful entry and infection.
\end{abstract}

Findings: Treating HSV-1 bound to B78 or CHO cells with PEG allowed viral entry as measured by virus-induced beta-galactosidase activity. Based on the mechanism of PEG action, we propose that entry likely proceeds by direct fusion of HSV particles with the plasma membrane. Under the conditions tested, PEG-mediated infection of $\mathrm{CHO}$ cells progressed to the level of HSV late gene expression, while B78 cells supported HSV DNA replication. We tested whether proteolysis or acidification of cell-bound virions could trigger HSV fusion with the plasma membrane. Under the conditions tested, mildly acidic $\mathrm{pH}$ of 5-6 or the protease trypsin were not capable of triggering HSV-1 fusion as compared to PEG-treated cell-bound virions.

Conclusions: B78 cells and CHO cells, which typically endocytose HSV prior to viral penetration, are capable of supporting HSV-1 entry via direct penetration. HSV capsids delivered directly to the cytosol at the periphery of these cells complete the entry process. B78 and $\mathrm{CHO}$ cells may be utilized to screen for factors that trigger entry as a consequence of fusion of virions with the cell surface, and PEG treatment can provide a necessary control.

Keywords: Herpesviruses, Herpes simplex virus, Viral entry, Virus-cell fusion, Membrane fusion, Endocytosis, Receptors, Low pH

\section{Background}

To accomplish entry via virus-cell membrane fusion, viruses depend on one or more cellular triggers such as endosomal $\mathrm{pH}$, receptor engagement, and/or enzymatic cleavage [1-6]. The host requirements for herpesviral fusion and entry are incompletely defined. Herpes simplex virus (HSV) binds to a cellular receptor such as nectin-1

\footnotetext{
*Correspondence: nicola@vetmed.wsu.edu

${ }^{\dagger}$ Equal contributors

'Department of Veterinary Microbiology and Pathology, College of Veterinary Medicine, Washington State University, Pullman, WA 99164, USA

${ }^{2}$ Paul G. Allen School for Global Animal Health, Washington State University, Pullman, WA 99164, USA
}

or HVEM. This interaction is essential, but it is not clear if it is sufficient for fusion and entry [7, 8]. There is mounting evidence for additional cellular cues for HSV entry such as intracellular low $\mathrm{pH}[9-14]$ and receptors bind either $\mathrm{gB}$ [15-17] or $\mathrm{gH}[18-21]$.

$\mathrm{V}$ is able to traverse a $\mathrm{pH}$-dependent, endocytic pathepithelial lines including epidernal keratinocytes occurs via a low $\mathrm{pH}$-dependent pathway similar to CHO-receptor cells [9, 10, 21, 25-27]. Entry into human neuronal SY5Y 
cells and human epidermal cell line A431 proceeds via a pathway similar to that in B78-receptor cells [10, 24]. In addition, HSV enters several human neuronal cell types and model Vero cells by direct, $\mathrm{pH}$-independent penetration at the plasma membrane [10, 28-31]. An emerging theme for herpesvirus entry is the utilization of endocytic and non-endocytic routes in a cell typedependent manner [9, 10, 32-37].

Receptor-deficient cells have been valuable tools for understanding HSV entry. For example, the screening of expression libraries in $\mathrm{CHO}$ cells was a key approach in the identification of several cellular entry factors and receptors for HSV [15, 38-41]. B78 and CHO cells are both resistant to HSV-1 entry [42, 43]. However, when provided with a gD-receptor such as nectin-1, these cells support HSV entry by an endocytosis pathway.

The full complement of cellular factors that are sufficient for HSV entry is not clear. Receptor-negative cells that normally support entry by endocytosis are excellent tools to screen for factors that trigger HSV-cell fusion. In order for such a system to be useful, entry that results from fusion with the plasma membrane must be detectable. Since HSV entry pathway varies with cell type, it is possible that cells that typically support HSV capsid release and penetration from an endocytic compartment may not properly target a capsid that appears in the cell periphery. In fact, Semliki Forest Virus, which normally enters by endocytosis, can be artificially fused with the plasma membrane of $\mathrm{CHO}$ cells as detected by electron microscopy. However, the de-enveloped SFV capsid remains trapped in the cell periphery and complete entry and infection does not occur [44]. The chemical fusogen, polyethylene glycol (PEG) has been utilized to artificially fuse HSV with cells to analyze envelope glycoprotein function [45-47]. PEG has been underutilized as a means to address cellular factors involved in HSV entry and fusion. Here, we use PEG-mediated fusion to determine that HSV receptor-negative $\mathrm{B} 78$ and $\mathrm{CHO}$ cells are able to support the plasma membrane route of entry. We then use this model system to evaluate the ability of a protease and low $\mathrm{pH}$ to trigger virus-cell fusion.

\section{Results and discussion}

B78H1 Gal11 cells (referred to as B78 cells in this study) are mouse melanoma cells derived from parental $\mathrm{B} 78 \mathrm{H} 1$ cells, which are resistant to HSV entry. B78 cells are stably transformed with the Escherichia coli lacZ gene under the control of the HSV ICP4 promoter. B78C10 cells (referred to as B78-nectin-1 cells in this study) stably express the lac $Z$ gene and the human gD-receptor nectin-1. Nectin-1 renders B78 cells susceptible to HSV entry. CHO-IE $\beta 8$ cells are a hamster cell line derived from the parental CHO-K1 cell line and are stably transformed with the Escherichia coli lacZ gene under the control of the HSV ICP4 promoter. CHO-nectin-1 (M3A) cells are CHO-IE $\beta 8$ cells stably transformed with the human nectin-1 gene. The beta-galactosidase reporter assay is widely used as an indicator of HSV entry.

As expected [42, 43], adding HSV-1 at an MOI of 10 to wild type $\mathrm{B} 78$ or $\mathrm{CHO}$ cells did not result in detectable viral entry (Fig. 1a and c) as measured by beta-galactosidase activity. PEG 6000 solid (Sigma) was melted in an Amsco autoclave (STERIS, Mentor, OH). A $1 \mathrm{~g} / \mathrm{ml}$ solution of PEG 6000 in serum-free cell culture medium was incubated at $37^{\circ} \mathrm{C}$ until dissolved. Ice-cold HSV-1 strain KOS was added to confluent cell monolayers (MOI of 10) for $2 \mathrm{~h}$ at $4{ }^{\circ} \mathrm{C}$ to allow for cell binding. Cultures were washed with warm PBS. Cell-bound virus was treated with PEG 6000 or mocktreated. PEG solution was added to the cell surface for $30 \mathrm{~s}$, and then cells were rinsed thrice with warm PBS. Complete cell culture medium was then added to cells. When PEG 6000 was added to HSV-1 bound to the surface of either B78 or CHO cells, viral entry was detected as determined by beta-galactosidase activity (Fig. 1a and c). PEG has also been shown to mediate infection of swine testis (ST) cells, which are resistant to HSV-1 entry [48]. The mode of HSV1 entry into ST cells has not been established. In the B78 and $\mathrm{CHO}$ cells used in this study, following membrane fusion, tegument VP16 is translocated to the nucleus and induces beta-galactosidase expression driven by the ICP4 promoter. These results suggest that PEG successfully triggered fusion between the viral envelope and the plasma membrane. When an appropriate gD-receptor is present, the subcellular site of fusion in both $\mathrm{B} 78$ and $\mathrm{CHO}$ cells is an internal, endosomal membrane. Thus, if appropriate conditions are provided, $\mathrm{HSV}-1$ can fuse with the plasma membrane of cells that typically support viral endocytosis. This fusion can be detected by downstream reporter gene expression.

If the enhanced beta-galactosidase signal in the PEGtreated samples (Fig. 1a) is due to HSV-1 entry, then adding increasing amounts of HSV-1 should result in a concomitant increase in reporter expression. Indeed, beta-galactosidase activity increased in a virus dosedependent manner when MOIs ranging from 0 to 10 were tested in the PEG experiment on wild type B78 and $\mathrm{CHO}$ cells (Fig. $1 \mathrm{~b}$ and d). Importantly, PEG treatment of $\mathrm{CHO}$ or B78 cells in the absence of virus did not result in beta-galactosidase activity above background (MOI of 0 in Fig. $1 \mathrm{~b}$ and d). To our knowledge, this is the first demonstration of PEG rescuing HSV infection of receptor-negative $\mathrm{CHO}$ and $\mathrm{B} 78$ cells. PEG has been used previously to rescue the fusion activity of fusion-dead virus mutants [45-47]. We gauged the efficiency of PEG-triggered entry as compared to gDreceptor-mediated entry via endocytosis. In general, PEG-mediated entry into the receptor-negative cells was less efficient than entry into the corresponding cells 

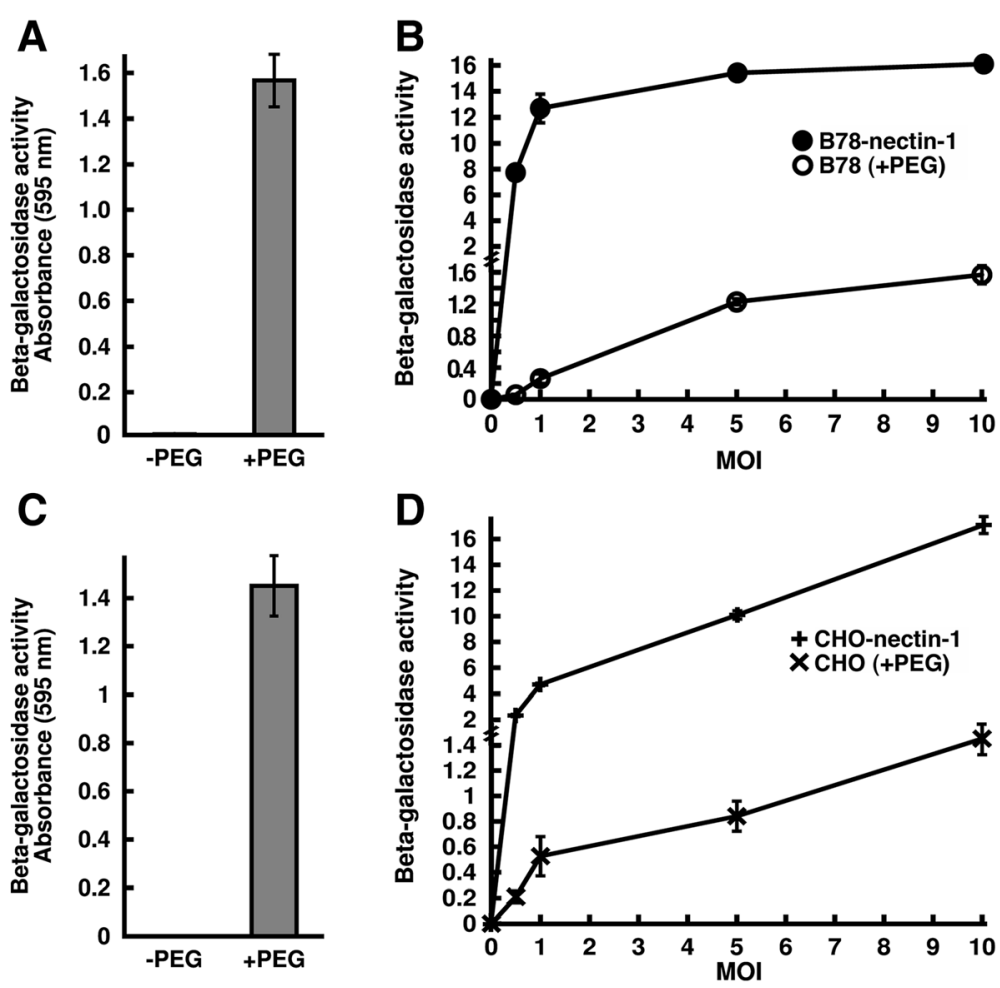

Fig. 1 PEG-mediated entry of HSV-1 into cells that are resistant to entry and that normally mediate entry via an endocytosis pathway. HSV-1 strain KOS was bound to B78 cells (a) or CHO cells (c) (MOI of 10) for $2 \mathrm{~h}$ at $4{ }^{\circ} \mathrm{C}$. Cell bound virus was treated with PEG 6000 (+ PEG) or mock-treated (- PEG). At $7 \mathrm{~h}$ post-infection, beta-galactosidase activity was detected as an indication of viral entry [74]. b, d HSV-1 KOS was bound to B78 and B78-nectin-1 cells (b) or $\mathrm{CHO}$ and $\mathrm{CHO}$-nectin-1 cells (d) for $2 \mathrm{~h}$ at $4{ }^{\circ} \mathrm{C}$ at the indicated $\mathrm{MOls}$ ranging from 0.5 to 10 . B78 and $\mathrm{CHO}$ cell samples were treated with PEG and B78-nectin-1 and CHO-nectin-1 samples were mock treated. Beta-galactosidase activity was measured at $7 \mathrm{~h}$ p.i. $\mathbf{b}$, $\mathbf{d}$ To allow a more direct comparison between samples of disparate reactivity, a fraction of the B78-nectin-1 and CHO-nectin-1 samples was measured. Values shown represent the beta-galactosidase activity from equivalent cell numbers. Each value is the mean of quadruplicate determinations with standard deviation. One representative experiment of at least three independent experiments is shown

expressing the gD-receptor nectin-1 (Fig. $1 \mathrm{~b}$ and d). At all MOIs tested for $\mathrm{CHO}$ cells and at the higher MOIs of 5 and 10 for the B78 cells, the nectin-1 expressing cells supported entry $\sim 9$ to 12 -times more effectively than PEGinduced fusion in the respective receptor-negative cells. Furthermore, PEG-mediated entry into B78 cells at the lowest MOIs tested (0.5 and 1) was $~ 40$ to 70 times less efficient than entry into B78-nectin-1 cells (Fig. 1b). These differences may be even greater when comparing fully entry-competent viral samples (if these could be obtained), as it is possible that PEG fusion might permit infection by virions that would otherwise be defective for a receptordependent entry pathway. In contrast to HSV-1, HSV-2 strains successfully enter wild type $\mathrm{CHO}$ cells $[41,42]$, so it is of future interest to determine the effect of PEG treatment on HSV-2.

We microscopically examined the effect of PEG treatment on HSV infectivity of receptor-negative cells. As expected, addition of HSV-1 alone to wild type B78 or $\mathrm{CHO}$ cells resulted in no detectable infected cells (Fig. 2b and $f$ ), virtually indistinguishable from uninfected cells (Fig. 2a and e). This is consistent with the resistance of
B78 cells and $\mathrm{CHO}$ cells to HSV-1 entry. PEG treatment of HSV-1 bound to B78 cells followed by $24 \mathrm{~h}$ infection resulted in HSV-antigen positive, single cells and small clusters of cells, as detected by immunoperoxidase staining with an anti-HSV polyclonal antibody (Fig. 2d). This is visual evidence that PEG mediates HSV entry into receptor-negative B78 cells. Treatment with PEG alone did not result in HSV antigen staining in this assay (Fig. 2c). HSV forms large plaques comprised of dozens of infected cells on B78 cells that express gD-receptors such as nectin-1 and HVEM, consistent with a gDreceptor allowing entry [43]. The single-infected cells and small plaques in the PEG treated samples (Fig. 2d) are consistent with the requirement of gD-receptors to mediate spread between B78 cells [49].

In contrast to the B78 cell result, PEG treatment of HSV-1 bound to $\mathrm{CHO}$ cells followed by $24 \mathrm{~h}$ infection did not result in detection of HSV-antigen positive cells (Fig. 2h). Thus, although PEG mediates entry of HSV-1 into receptor-negative $\mathrm{CHO}$ cells as measured by reporter gene expression (Fig. 1), synthesis of viral antigens is not detected by immunoperoxidase staining of fixed cells at 


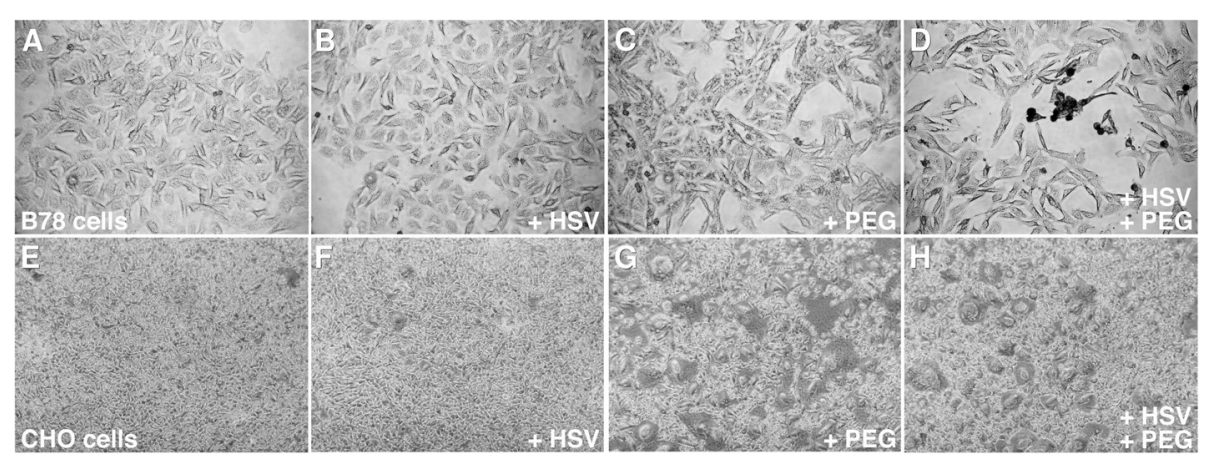

Fig. 2 Microscopic analysis of the effect of PEG 6000 on HSV-1 infection of receptor-negative cells. B78 cells (a-d) or CHO cells (e-h) were infected with HSV-1 strain KOS (MOI of 10) (b, d, $\mathbf{f}, \mathbf{h})$ or remained uninfected $(\mathbf{a}, \mathbf{c}, \mathbf{e}, \mathbf{g})$ for $2 \mathrm{~h}$ at $4{ }^{\circ} \mathrm{C}$. Cultures were treated with PEG 6000 (c, $\left.\mathbf{d}, \mathbf{g}, \mathbf{h}\right)$ or mock-treated $(\mathbf{a}, \mathbf{b}, \mathbf{e}, \mathbf{f})$. At $24 \mathrm{~h}$ post-infection (p.i.), cultures were fixed with ice-cold methanol-acetone solution $\left(2: 1\right.$ ratio) for $20 \mathrm{~min}$ at $-20^{\circ} \mathrm{C}$ and air dried. HSV antigen-positive cells were detected by immunoperoxidase staining with anti-HSV polyclonal antibody HR50 (Fitzgerald Industries, Concord, MA) [75]. Magnification, 5X

24 h. CHO cells that express gD-receptors do not support wild type HSV-1 plaque formation [39, 42]. Together with Fig. 1c and d, these results support the notion that betagalactosidase reporter gene expression is more sensitive for detecting entry into $\mathrm{CHO}$ cells than is staining cells for HSV-specific antigen. Interestingly, treatment of $\mathrm{CHO}$ cells with PEG alone caused noticeable cell-cell fusion (Fig. 2g). Similar fusion was not detected with B78 cells (Fig. 2c). That $\mathrm{CHO}$ cells are prone to fusion is important for interpreting results from HSV cell-cell fusion assays, in which $\mathrm{CHO}$ cells have been widely used [50-53]. In fact, when $\mathrm{CHO}$ cell preparations are mixed in fusion assays the background fusion can be high ([50]; data not shown).

To explore how far infection progresses following PEG fusion of HSV-1 with B78 and $\mathrm{CHO}$ cells, viral gene expression and replication were measured by reverse transcriptase-qPCR with the indicated primers (Table 1). PEG-mediated entry of HSV-1 into B78 and $\mathrm{CHO}$ cells resulted in detectable expression of HSV-1 mRNAs representative of the immediate early (ICP27), early (thymidine kinase), and late $(\mathrm{gC})$ gene classes

Table 1 Primers used in this study

\begin{tabular}{ll}
\hline Gene & Primer sequence $\left(5^{\prime}-3^{\prime}\right)$ \\
\hline HSV-1 ICP22 & GAGTTTGGGAGTTG \\
GSV-1 ICP47 & ACCGCTTCCTGCTCGT \\
HSV-1 TK & ACGCCCCCTTTATTG \\
& TCGGTCACGGCATAAGGC \\
HSV-1 gC & CAGCAAGAAGCCACGGAAGT \\
& GTCCACCCTGCCCATTTC \\
Mouse GAPDH & CGGACGACGTACACGATTGC \\
& CGACTTCAACAGCAACTCCCACTCTTCC \\
& TGGTGGTCCAGGGTTCTTACTCCTT
\end{tabular}

aPrimers modified from reference [76] to remove dimers and hairpins
(Fig. $3 a$ and $b$ ). Detection of these specific proteins was not attempted. If viral proteins are indeed synthesized in PEG-treated $\mathrm{CHO}$ cells, the levels are likely too low to be detected by the antigen staining in Fig. 2. However, HSV-induced beta-galactosidase is clearly produced in these cells (Fig. 1).

PEG fusion of HSV-1 with B78 cells resulted in de novo synthesized viral genomic DNA as detected by qPCR (Fig. 4a). However, when an MOI as high as 30 was tested, extracellular progeny virions above the input inoculum were not detected. PEG-induced HSV-1 entry into $\mathrm{CHO}$ cells did not result in detectable viral DNA replication (Fig. 4b). CHO cells expressing the receptor HVEM are reportedly permissive for viral replication [39]. PEGmediated entry into $\mathrm{CHO}$ cells at higher MOI might result in detectable HSV-1 replication. Likewise higher MOI in B78 cells might result in egress of progeny virions. HSV-1 infection of the permissive control cell line, B78-nectin-1 (MOI of 10), resulted in detectable viral DNA both inside the infected cell and in the extracellular medium (Fig. 4c). This is consistent with the ability of B78-nectin-1 cells to support HSV-1 plaque formation. Alternatively, nectin-1 may somehow rescue a post-replication defect in HSVinfected B78 cells. Thus, PEG fusion leads to successful entry, albeit at lower efficiency than nectin-1-mediated endocytosis, consistent with the results from Fig. 1. Together the results suggest that direct deposit of the nucleocapsid into the cytosol at the plasma membrane of $\mathrm{CHO}$ or $\mathrm{B} 78$ cells results in successful entry leading to viral gene expression or replication, respectively.

Cellular receptors that bind to gD are required for HSV entry, but it is not known whether they are sufficient. Since direct fusion of HSV-1 with receptor-negative cells results in entry without the need for endocytosis (Fig. 1), we were able to directly test potential triggers of virus-cell fusion. During entry of several viruses, cleavage of viral surface proteins by cellular endosomal proteases is a 


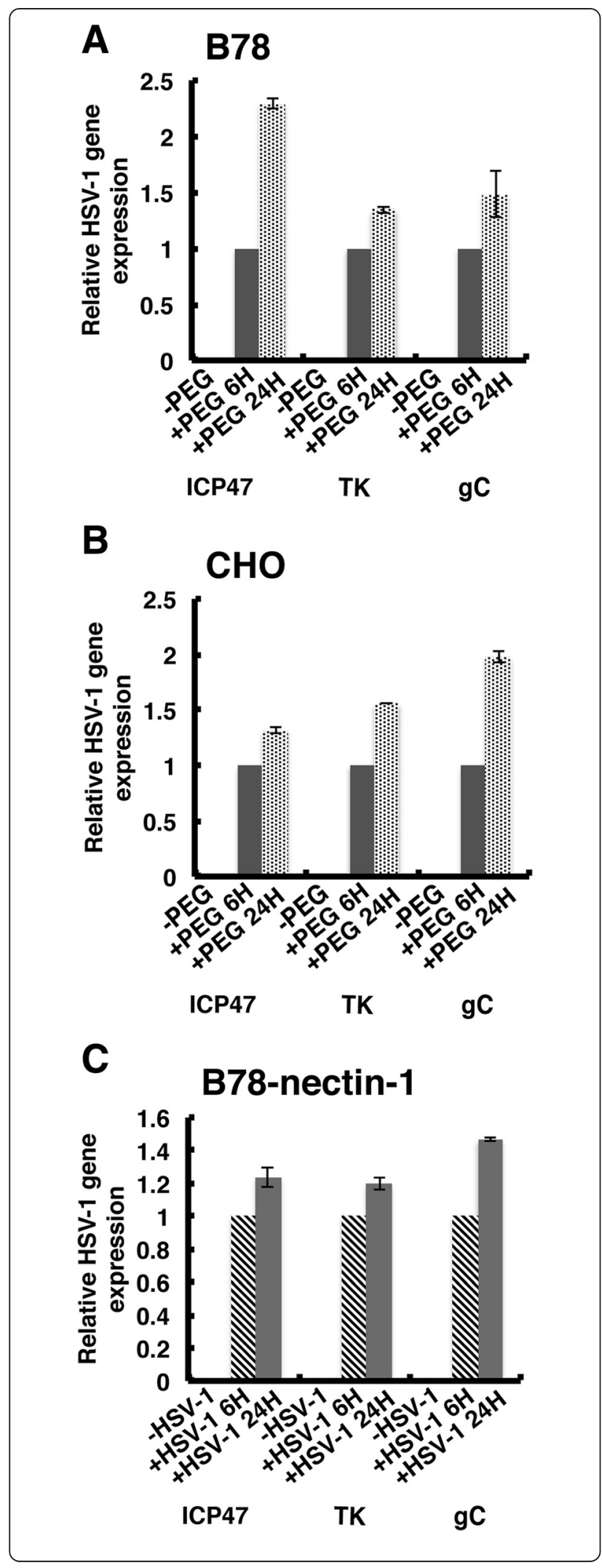

Fig. 3 PEG-mediated entry leads to HSV-1 gene expression. At 6 or $24 \mathrm{~h}$ following either PEG treatment of HSV-1 bound to (a) B78 or (b) $\mathrm{CHO}$ cells or (c) following HSV-1 infection of B78-nectin-1 cells, RNA was extracted with TRIzol (Ambion). Following DNase treatment, firststrand CDNA was synthesized from 1.75 micrograms of total RNA using SuperScript VILO (Invitrogen). Equal volumes of cDNA were used to quantify HSV-1 gene ICP27, thymidine kinase (TK) and gC transcripts with Sso Advanced Sybr Green SuperMix (Bio-Rad), using a Bio-Rad CFX96 Real Time System. The quantity of HSV-1 mRNAs, normalized to cellular GAPDH, is shown relative to mRNA from $6 \mathrm{~h}$ post-PEG fusion

requirement for entry $[4,6,54,55]$. In vitro protease treatment of viral particles can sometimes substitute for the cleavage during entry, and has been used for evidence that proteolysis is required for entry. We tested whether trypsin treatment of HSV-1 could trigger fusion with the surface of B78 cells as measured by beta-galactosidase expression. $\mathrm{CHO}$ cells were omitted from this analysis because of their sensitivity to even the lowest concentrations of trypsin tested (data not shown). HSV-1 was bound to the $\mathrm{B} 78$ plasma membrane at $4{ }^{\circ} \mathrm{C}$, and then treated with increasing concentrations of trypsin. For limited proteolysis experiments, proteases are often added at $4{ }^{\circ} \mathrm{C}$ at which they are active ([56], unpublished data). Trypsin treatment under these conditions did not result in detectable viral entry (Fig. 5a). Importantly, control PEG treatment of cell-bound HSV-1 induced entry. In addition, inhibitors of cathepsins B and L do not block HSV entry [57]. We cannot discard the possibility that a distinct proteolytic event that is not mimicked by the trypsin treatments tested may yet play a role in HSV entry.

HSV requires intracellular low $\mathrm{pH}$ in a cell-specific manner [9, 11, 12, 22, 23]. Agents that alter endosomal $\mathrm{pH}$ such as bafilomycin A1 and ammonium chloride inhibit HSV entry into epithelial cells but not neurons [10]. $\mathrm{HSV}$ gB is triggered by low $\mathrm{pH}$ to undergo conformational changes [14, 58-62]. We have proposed that $\mathrm{pH}$ activates $\mathrm{gB}$ to trigger membrane fusion in part because the antigenic profile of low $\mathrm{pH}$-treated $\mathrm{gB}$ is similar to that of the highly fusogenic $\mathrm{gB}$ present in fusion-fromwithout strains of HSV [63]. The entry requirement for low $\mathrm{pH}$ is shared by several herpesviruses, often in a cell-dependent manner [36, 64-66]. However, direct demonstration that acid $\mathrm{pH}$ triggers herpesviral fusion has remained elusive. We therefore asked whether low $\mathrm{pH}$ is able to directly trigger fusion of the HSV-1 envelope with the plasma membrane of a target cell. HSV-1 was bound to the B78 cell surface and then treated with different pHs. Treatment with pHs of 5.7 or 4.5 did not trigger HSV-1 entry above the background level detected when cells were treated with PEG in the absence of HSV (Fig. 5b). PEG treatment of cell-bound HSV-1 allowed entry and was included as a critical control. The current experiments suggest that proteolysis or low $\mathrm{pH}$ alone is not sufficient for entry. One explanation may be that a 


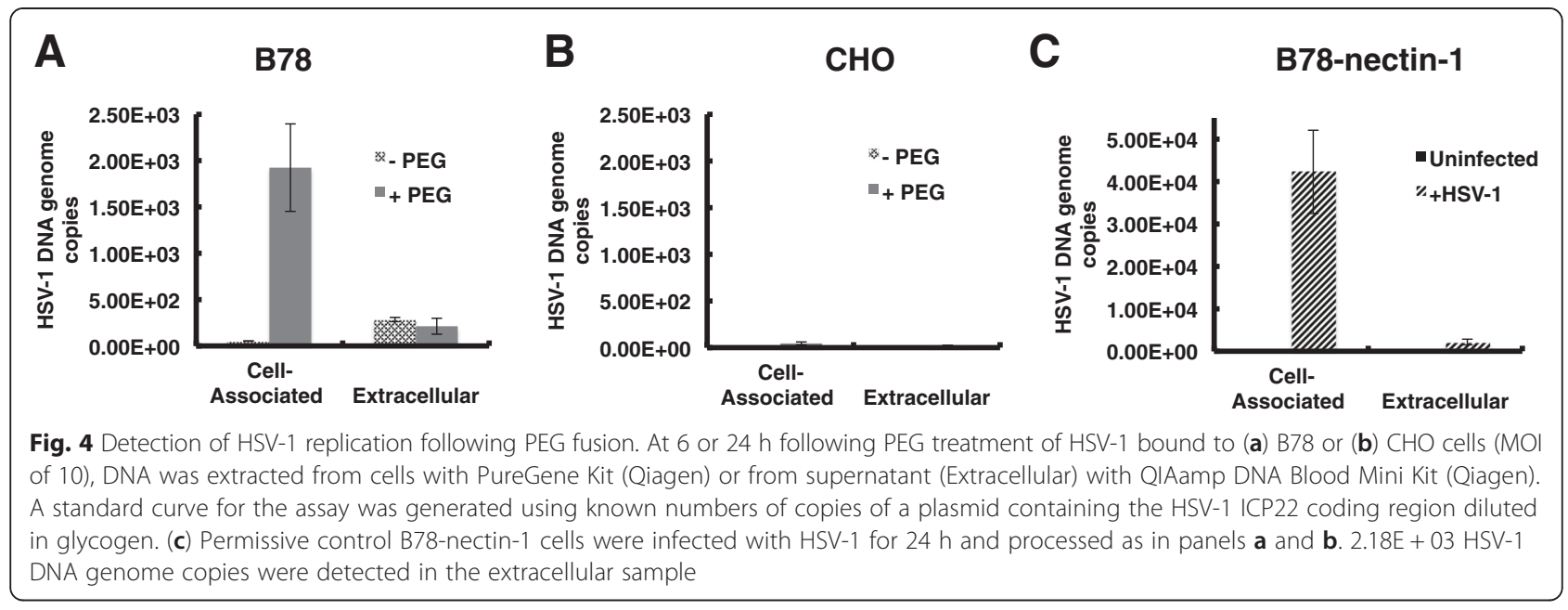
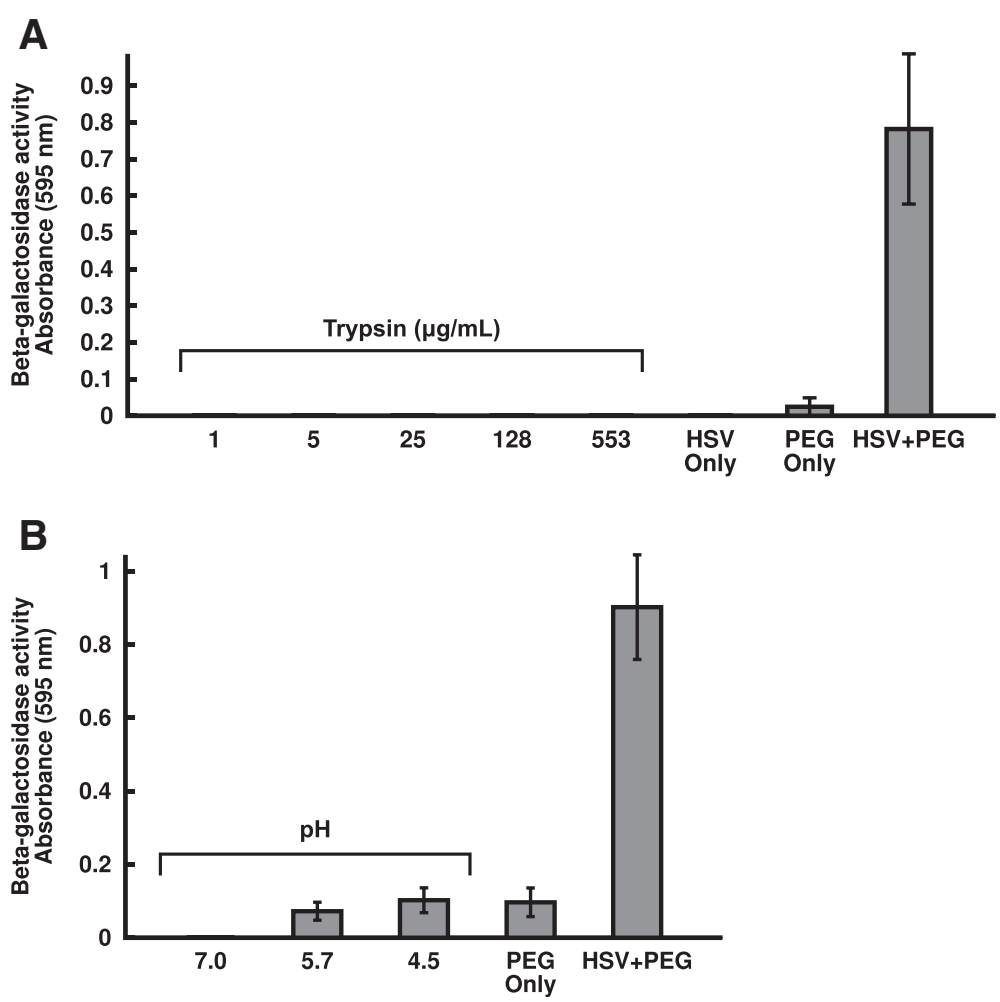

Fig. 5 Inability of protease or low pH treatments alone to trigger fusion with the plasma membrane of entry-resistant cells. HSV-1 KOS was bound to B78 cells (MOl of 10) for $2 \mathrm{~h}$ at $4{ }^{\circ} \mathrm{C}$. a Confluent cell monolayers were chilled at $4{ }^{\circ} \mathrm{C}$ and washed with ice-cold PBS. HSV-1 strain KOS in bicarbonate-free culture medium supplemented with $20 \mathrm{mM} \mathrm{Hepes}$ and $0.2 \% \mathrm{BSA}$ was added at an $\mathrm{MOI}$ of 10 for $2 \mathrm{~h}$ at $4{ }^{\circ} \mathrm{C}$. Monolayers were rinsed with ice-cold PBS, and then PBS containing different concentrations of trypsin was added to cells for 25 min at $4{ }^{\circ} \mathrm{C}$. Trypsinization was halted by addition of soybean trypsin inhibitor (8000-16,000 BAEE units; GIBCO-BRL) and $5 \%$ fetal bovine serum for 15 min at room temperature. Complete cell culture medium was added, and cultures were incubated for $7 \mathrm{~h}$ at $37^{\circ} \mathrm{C}$. b Serum-free, bicarbonate-free culture medium with $0.2 \%$ BSA and 5 mM (each) HEPES (Life Technologies), 2-(N-morpholino)ethanesulfonic acid (MES; Sigma), and sodium succinate (Sigma) was adjusted with $\mathrm{HCl}$ to achieve pHs ranging from 7.0 to 4.5 [69]. Confluent cell monolayers were chilled at $4{ }^{\circ} \mathrm{C}$ and washed with ice-cold PBS. HSV-1 strain KOS was added at an MOI of 10 for $2 \mathrm{~h}$ at $4{ }^{\circ} \mathrm{C}$. Cells were washed with warm PBS. Warmed media adjusted to different pHs were added. Samples were incubated at $37^{\circ} \mathrm{C}$ for $10 \mathrm{~min}$. A pre-titrated amount of $\mathrm{NaOH}$ was added to return each sample to $\mathrm{pH}$ 7.4. Complete cell culture medium was added, and cultures were incubated for $7 \mathrm{~h}$ at $37^{\circ} \mathrm{C}$. Each value is the mean of quadruplicate determinations with standard deviation. Representative experiments of at least three independent experiments are shown 
cascade of interactions with multiple cellular factors is necessary for fusion. The sequence of these interactions may also be critical.

Soluble, membrane-truncated, gD-receptors can also mediate HSV entry into B78 and $\mathrm{CHO}$ receptor-negative cells, but it is not known whether entry occurs at the plasma membrane $[13,67]$. In fact, $\mathrm{CHO}$ cells endocytose herpes simplex virions and target them to a degradative pathway in the absence of known membrane-bound gDreceptors [11], so soluble gD-receptors may mediate entry via a $\mathrm{CHO}$ endosomal compartment. The current study cannot rule out that PEG treatment may somehow trigger fusion with the endosomal membrane. However, this is unlikely because PEG was added when virions were bound to the cell surface, and PEG causes fusion by complete mixing of the inner and outer leaflets of both membranes. To begin to address the mechanism of PEG-mediated fusion, we tested the ability of PEG to rescue the infectivity of cell-bound HSV-1 that was inactivated by sodium citrate buffer ( $\mathrm{pH}$ 3.0). Low $\mathrm{pH}$ has long been known to inactivate $\mathrm{HSV}$, but the mechanism of inactivation is not known [9, 59, 68-70]. PEG failed to rescue the inactivated virions as measured by beta-galactosidase reporter expression for reasons that are not clear (data not shown). Interestingly, this contrasts with the PEG rescue of HSV-1 mutants that lack either gD or gB $[46,47]$. One explanation of our results is that PEG substitutes for a specific step(s) in the HSV fusion process and that PEG works together with the viral envelope to mediate full fusion. Under the conditions tested, low $\mathrm{pH}$ or trypsin were not capable of triggering HSV-1 fusion. This may suggest that neither is sufficient to substitute for the presence of a gDreceptor. It is possible that a combination of multiple host cell factors is necessary for HSV-1 fusion [3, 71-73]. Thus a sequential application of low $\mathrm{pH}$, protease, and/or gDreceptors may be needed to mediate fusion of HSV-1 with the surface of receptor-negative cells. We demonstrate that B78 and CHO cells can be employed for such studies because PEG treatment of HSV-1 bound to cells likely results in fusion with the plasma membrane of these cells. Once identified, candidate molecules that permit HSV to fuse with the surface of $\mathrm{B} 78$ or $\mathrm{CHO}$ cells would be tested and confirmed in more physiologically relevant human cells.

\section{Conclusions}

B78 cells and $\mathrm{CHO}$ cells, which typically endocytose HSV prior to viral penetration, are capable of supporting HSV-1 entry via direct penetration and may be utilized to screen for factors required for fusion of virions with the cell surface. PEG treatment can provide a needed control because it artificially fuses HSV with the host cell and results in HSV gene expression, and in the case of B78 cells, detectable viral replication. Compared to control entry mediated by PEG, the protease and $\mathrm{pH}$ conditions tested did not mediate penetration of HSV-1 at the cell surface of receptor-negative cells. One explanation is that a cascade of interactions with multiple cellular factors is likely necessary for fusion.

\section{Abbreviations}

CHO: Chinese hamster ovary; gC: glycoprotein C; gD: glycoprotein D; HSV: Herpes simplex virus; HSV-1: Herpes simplex virus type 1; HSV-2: Herpes simplex virus type 2; HVEM: Herpes virus entry mediator; ICP22: Infected cell protein 22; ICP27: Infected cell protein 27; MOI: Multiplicity of infection; PBS: Phosphate buffered saline; PCR: Polymerase chain reaction; PEG: Polyethylene glycol.

\section{Competing interests}

The authors declare that they have no competing interests.

\section{Authors' contributions}

EJW, SMP, CWC and AVN conceived and designed the experiments. EJW and SMP performed the experiments. EJW, SMP, HAC, and AVN analyzed data and wrote the paper. All authors read and approved the final manuscript.

\section{Acknowledgments}

This investigation was supported by Public Health Service grant Al119159 from the National Institute of Allergy and Infectious Diseases. We are grateful to Santanu Bose, Gary Cohen, Roselyn Eisenberg and Patricia Spear for gifts of reagents.

Received: 16 July 2015 Accepted: 12 November 2015

Published online: 16 November 2015

\section{References}

1. Nicola AV, Aguilar HC, Mercer J, Ryckman B, Wiethoff CM. Virus entry by endocytosis. Adv Virol. 2013;2013:469538. doi:10.1155/2013/469538.

2. Mercer J, Schelhaas M, Helenius A. Virus entry by endocytosis. Annu Rev Biochem. 2010;79:803-33

3. Barrow E, Nicola AV, Liu J. Multiscale perspectives of virus entry via endocytosis. Virol J. 2013;10:177. doi:10.1186/1743-422X-10-177.

4. Chandran K, Sullivan NJ, Felbor U, Whelan SP, Cunningham JM. Endosomal proteolysis of the Ebola virus glycoprotein is necessary for infection. Science. 2005:308(5728):1643-5.

5. Mothes W, Boerger AL, Narayan S, Cunningham JM, Young JA. Retroviral entry mediated by receptor priming and low $\mathrm{pH}$ triggering of an envelope glycoprotein. Cell. 2000;103(4):679-89.

6. Ebert DH, Deussing J, Peters C, Dermody TS. Cathepsin L and cathepsin B mediate reovirus disassembly in murine fibroblast cells. J Biol Chem. 2002; 277(27):24609-17.

7. Spear PG, Eisenberg RJ, Cohen $\mathrm{GH}$. Three classes of cell surface receptors for alphaherpesvirus entry. Virology. 2000;275(1):1-8.

8. Campadelli-Fiume G, Cocchi F, Menotti L, Lopez M. The novel receptors that mediate the entry of herpes simplex viruses and animal alphaherpesviruses into cells. Rev Med Virol. 2000;10(5):305-19.

9. Nicola AV, McEvoy AM, Straus SE. Roles for endocytosis and low pH in herpes simplex virus entry into HeLa and Chinese hamster ovary cells. J Virol. 2003;77(9):5324-32.

10. Nicola AV, Hou J, Major EO, Straus SE. Herpes simplex virus type 1 enters human epidermal keratinocytes, but not neurons, via a pH-dependent endocytic pathway. J Virol. 2005;79(12):7609-16.

11. Nicola AV, Straus SE. Cellular and viral requirements for rapid endocytic entry of herpes simplex virus. J Virol. 2004;78(14):7508-17.

12. Clement C, Tiwari V, Scanlan PM, Valyi-Nagy T, Yue BY, Shukla D. A novel role for phagocytosis-like uptake in herpes simplex virus entry. J Cell Biol. 2006;174(7):1009-21.

13. Whitbeck JC, Zuo Y, Milne RS, Cohen GH, Eisenberg RJ. Stable association of herpes simplex virus with target membranes is triggered by low $\mathrm{pH}$ in the presence of the gD receptor, HVEM. J Virol. 2006;80(8):3773-80.

14. Dollery SJ, Delboy MG, Nicola AV. Low pH-induced conformational change in herpes simplex virus glycoprotein B. J Virol. 2010;84(8):3759-66.

15. Satoh T, Arii J, Suenaga T, Wang J, Kogure A, Uehori J, et al. PILRalpha is a herpes simplex virus-1 entry coreceptor that associates with glycoprotein B. Cell. 2008;132(6):935-44. 
16. Bender FC, Whitbeck JC, Lou H, Cohen GH, Eisenberg RJ. Herpes simplex virus glycoprotein B binds to cell surfaces independently of heparan sulfate and blocks virus entry. J Virol. 2005;79(18):11588-97.

17. Suenaga $T$, Satoh T, Somboonthum $P$, Kawaguchi $Y$, Mori $Y$, Arase H. Myelin-associated glycoprotein mediates membrane fusion and entry of neurotropic herpesviruses. Proc Natl Acad Sci U S A. 2010;107(2):866-71.

18. Scanlan PM, Tiwari V, Bommireddy S, Shukla D. Cellular expression of $\mathrm{gH}$ confers resistance to herpes simplex virus type-1 entry. Virology. 2003; 312(1):14-24.

19. Parry C, Bell S, Minson T, Browne $H$. Herpes simplex virus type 1 glycoprotein $H$ binds to alphavbeta3 integrins. J Gen Virol. 2005;86(Pt 1):7-10.

20. Gianni T, Cerretani A, Dubois R, Salvioli S, Blystone SS, Rey F, et al. Herpes simplex virus glycoproteins $\mathrm{H} / \mathrm{L}$ bind to cells independently of \{alpha\}V\{beta\}3 integrin and inhibit virus entry, and their constitutive expression restricts infection. J Virol. 2010;84(8):4013-25.

21. Gianni T, Salvioli S, Chesnokova LS, Hutt-Fletcher LM, Campadelli-Fiume G. alphavbeta6- and alphavbeta8-integrins serve as interchangeable receptors for HSV $\mathrm{gH} / \mathrm{gL}$ to promote endocytosis and activation of membrane fusion. PLoS Path. 2013;9(12):e1003806. doi:10.1371/journal.ppat.1003806.

22. Gianni T, Campadelli-Fiume G, Menotti L. Entry of herpes simplex virus mediated by chimeric forms of nectin1 retargeted to endosomes or to lipid rafts occurs through acidic endosomes. J Virol. 2004;78(22):12268-76.

23. Milne RS, Nicola AV, Whitbeck JC, Eisenberg RJ, Cohen GH. Glycoprotein D receptor-dependent, low-pH-independent endocytic entry of herpes simplex virus type 1. J Virol. 2005;79(11):6655-63.

24. Stiles KM, Milne RS, Cohen GH, Eisenberg RJ, Krummenacher C. The herpes simplex virus receptor nectin-1 is down-regulated after trans-interaction with glycoprotein D. Virology. 2008;373(1):98-111.

25. Rahn E, Petermann P, Hsu MJ, Rixon FJ, Knebel-Morsdorf D. Entry pathways of herpes simplex virus type 1 into human keratinocytes are dynamin- and cholesterol-dependent. PLoS One. 2011;6(10), e25464. doi:10.1371/journal. pone.0025464

26. Tiwari V, Oh MJ, Kovacs M, Shukla SY, Valyi-Nagy T, Shukla D. Role for nectin-1 in herpes simplex virus 1 entry and spread in human retinal pigment epithelial cells. Febs J. 2008;275(21):5272-85. doi:10.1111/j.1742-4658.2008.06655.x.

27. Shah A, Farooq AV, Tiwari V, Kim MJ, Shukla D. HSV-1 infection of human corneal epithelial cells: receptor-mediated entry and trends of re-infection. Mol Vis. 2010;16:2476-86

28. Fuller $A O$, Spear PG. Anti-glycoprotein D antibodies that permit adsorption but block infection by herpes simplex virus 1 prevent virion-cell fusion at the cell surface. Proc Natl Acad Sci U S A. 1987;84(15):5454-8.

29. Wittels $M$, Spear PG. Penetration of cells by herpes simplex virus does not require a low pH- dependent endocytic pathway. Virus Res. 1991;18(2-3):271-90.

30. Lycke E, Hamark B, Johansson M, Krotochwil A, Lycke J, Svennerholm B. Herpes simplex virus infection of the human sensory neuron. An electron microscopy study. Arch Virol. 1988;101(1-2):87-104.

31. Smith GA, Pomeranz L, Gross SP, Enquist LW. Local modulation of plus-end transport targets herpesvirus entry and egress in sensory axons. Proc Natl Acad Sci U S A. 2004;101(45):16034-9.

32. Raghu H, Sharma-Walia N, Veettil MV, Sadagopan S, Chandran B. Kaposi's sarcoma-associated herpesvirus utilizes an actin polymerization-dependent macropinocytic pathway to enter human dermal microvascular endothelial and human umbilical vein endothelial cells. J Virol. 2009;83(10):4895-911. doi:10.1128/JVI.02498-08.

33. Miller N, Hutt-Fletcher LM. Epstein-Barr virus enters B cells and epithelial cells by different routes. J Virol. 1992;66(6):3409-14.

34. Frampton Jr AR, Stolz DB, Uchida H, Goins WF, Cohen JB, Glorioso JC. Equine herpesvirus 1 enters cells by two different pathways, and infection requires the activation of the cellular kinase ROCK1. J Virol. 2007;81(20): 10879-89.

35. Van de Walle GR, Peters ST, VanderVen BC, O'Callaghan DJ, Osterrieder N. Equine herpesvirus 1 entry via endocytosis is facilitated by alphaV integrins and an RSD motif in glycoprotein D. J Virol. 2008;82(23):11859-68.

36. Ryckman BJ, Jarvis MA, Drummond DD, Nelson JA, Johnson DC. Human cytomegalovirus entry into epithelial and endothelial cells depends on genes UL128 to UL150 and occurs by endocytosis and low-pH fusion. J Virol. 2006;80(2):710-22

37. Hasebe R, Sasaki M, Sawa H, Wada R, Umemura T, Kimura T. Infectious entry of equine herpesvirus-1 into host cells through different endocytic pathways. Virology. 2009;393(2):198-209.
38. Shukla D, Liu J, Blaiklock P, Shworak NW, Bai X, Esko JD, et al. A novel role for 3-Osulfated heparan sulfate in herpes simplex virus 1 entry. Cell. 1999;99(1):13-22.

39. Montgomery RI, Warner MS, Lum BJ, Spear PG. Herpes simplex virus-1 entry into cells mediated by a novel member of the TNF/NGF receptor family. Cell. 1996;87(3):427-36.

40. Warner MS, Geraghty RJ, Martinez WM, Montgomery RI, Whitbeck JC, Xu R, et al. A cell surface protein with herpesvirus entry activity (HveB) confers susceptibility to infection by mutants of herpes simplex virus type 1, herpes simplex virus type 2, and pseudorabies virus. Virology. 1998;246(1):179-89.

41. Geraghty RJ, Krummenacher C, Cohen GH, Eisenberg RJ, Spear PG. Entry of alphaherpesviruses mediated by poliovirus receptor-related protein 1 and poliovirus receptor. Science. 1998;280(5369):1618-20.

42. Shieh MT, WuDunn D, Montgomery RI, Esko JD, Spear PG. Cell surface receptors for herpes simplex virus are heparan sulfate proteoglycans. J Cell Biol. 1992;116(5):1273-81.

43. Miller CG, Krummenacher C, Eisenberg RJ, Cohen GH, Fraser NW. Development of a syngenic murine B16 cell line-derived melanoma susceptible to destruction by neuroattenuated HSV-1. Mol Ther. 2001;3(2): 160-8. doi:10.1006/mthe.2000.0240.

44. Marsh M, Bron R. SFV infection in CHO cells: cell-type specific restrictions to productive virus entry at the cell surface. J Cell Sci. 1997;110(Pt 1):95-103.

45. Sarmiento M, Haffey M, Spear PG. Membrane proteins specified by herpes simplex viruses. III. Role of glycoprotein VP7(B2) in virion infectivity. J Virol. 1979;29(3):1149-58.

46. Ligas MW, Johnson DC. A herpes simplex virus mutant in which glycoprotein D sequences are replaced by beta-galactosidase sequences binds to but is unable to penetrate into cells. J Virol. 1988;62(5):1486-94.

47. Cai WH, Gu B, Person S. Role of glycoprotein B of herpes simplex virus type 1 in viral entry and cell fusion. J Virol. 1988;62(8):2596-604.

48. Subramanian G, McClain DS, Perez A, Fuller AO. Swine testis cells contain functional heparan sulfate but are defective in entry of herpes simplex virus. Journal of Virology. 1994;68(9):5667-76.

49. Even DL, Henley AM, Geraghty RJ. The requirements for herpes simplex virus type 1 cell-cell spread via nectin-1 parallel those for virus entry. Virus research. 2006;119(2):195-207.

50. Pertel PE, Fridberg A, Parish ML, Spear PG. Cell fusion induced by herpes simplex virus glycoproteins $\mathrm{gB}, \mathrm{gD}$, and $\mathrm{gH}-\mathrm{gL}$ requires a $\mathrm{gD}$ receptor but not necessarily heparan sulfate. Virology. 2001;279(1):313-24.

51. Cairns TM, Milne RS, Ponce-de-Leon M, Tobin DK, Cohen GH, Eisenberg RJ. Structure-function analysis of herpes simplex virus type $1 \mathrm{gD}$ and $\mathrm{gH}-\mathrm{gL}$ : clues from gDgH chimeras. J Virol. 2003;77(12):6731-42.

52. Tiwari V, Clement C, Duncan MB, Chen J, Liu J, Shukla D. A role for 3-O-sulfated heparan sulfate in cell fusion induced by herpes simplex virus type 1. J Gen Virol. 2004;85(Pt 4):805-9.

53. Fan $\mathrm{Q}$, Longnecker $\mathrm{R}$. The Ig-like $\mathrm{v}$-type domain of paired Ig-like type 2 receptor alpha is critical for herpes simplex virus type 1-mediated membrane fusion. J Virol. 2010;84(17):8664-72. doi:10.1128/JVI.01039-10.

54. Simmons G, Gosalia DN, Rennekamp AJ, Reeves JD, Diamond SL, Bates P. Inhibitors of cathepsin $L$ prevent severe acute respiratory syndrome coronavirus entry. Proc Natl Acad Sci U S A. 2005;102(33):11876-81.

55. Qiu Z, Hingley ST, Simmons G, Yu C, Das Sarma J, Bates P, et al. Endosomal proteolysis by cathepsins is necessary for murine coronavirus mouse hepatitis virus type 2 spike-mediated entry. J Virol. 2006;80(12):5768-76.

56. Pritchard SM, Cunha CW, Nicola AV. Analysis of herpes simplex virion tegument ICP4 derived from infected cells and ICP4-expressing cells. PLoS One. 2013;8(8), e70889. doi:10.1371/journal.pone.0070889.

57. Delboy MG, Nicola AV. A pre-immediate early role for tegument ICPO in the proteasome-dependent entry of herpes simplex virus. J Virol. 2011;85(12) 5910-18. doi:10.1128/JVI.00267-11.

58. Siekavizza-Robles CR, Dollery SJ, Nicola AV. Reversible conformational change in herpes simplex virus glycoprotein B with fusion-from-without activity is triggered by mildly acidic pH. Virol J. 2010;7:352. doi:10.1186/1743-422X-7-352.

59. Dollery SJ, Wright CC, Johnson DC, Nicola AV. Low-pH-dependent changes in the conformation and oligomeric state of the prefusion form of herpes simplex virus glycoprotein B are separable from fusion activity. J Virol. 2011; 85(19):9964-73. doi:10.1128/JVl.05291-11.

60. Stampfer SD, Lou H, Cohen GH, Eisenberg RJ, Heldwein EE. Structural basis of local, pH-dependent conformational changes in glycoprotein $\mathrm{B}$ from herpes simplex virus type 1. J Virol. 2010;84(24):12924-33. doi:10.1128/JVI.01750-10. 
61. Cairns TM, Whitbeck JC, Lou H, Heldwein EE, Chowdary TK, Eisenberg RJ, et al. Capturing the herpes simplex virus core fusion complex (gB-gH/gL) in an acidic environment. J Virol. 2011;85(13):6175-84. doi:10.1128/JVI.00119-11.

62. Muggeridge Ml. Glycoprotein B, of herpes simplex virus 2 has more than one intracellular conformation and is altered by low pH. J Virol. 2012;86(12): 6444-56. doi:10.1128/JVI.06668-11.

63. Roller DG, Dollery SJ, Doyle JL, Nicola AV. Structure-function analysis of herpes simplex virus glycoprotein B with fusion-from-without activity. Virology. 2008;382(2):207-16.

64. Akula SM, Naranatt PP, Walia NS, Wang FZ, Fegley B, Chandran B. Kaposi's sarcoma-associated herpesvirus (human herpesvirus 8) infection of human fibroblast cells occurs through endocytosis. J Virol. 2003;77(14):7978-90.

65. Finnen RL, Mizokami KR, Banfield BW, Cai GY, Simpson SA, Pizer LI, et al. Postentry events are responsible for restriction of productive varicella-zoster virus infection in Chinese hamster ovary cells. J Virol. 2006;80(21):10325-34.

66. Gillet L, Colaco S, Stevenson PG. Glycoprotein B switches conformation during murid herpesvirus 4 entry. J Gen Virol. 2008;89(Pt 6):1352-63.

67. Kwon H, Bai Q, Baek HJ, Felmet K, Burton EA, Goins WF, et al. Soluble V domain of Nectin-1/HveC enables entry of herpes simplex virus type 1 (HSV-1) into HSV-resistant cells by binding to viral glycoprotein D. J Virol. 2006;80(1):138-48.

68. Huang AS, Wagner RR. Penetration of herpes simplex virus into human epidermoid cells. Proc Soc Exp Biol Med. 1964;116:863-9.

69. Dollery SJ, Lane KD, Delboy MG, Roller DG, Nicola AV. Role of the UL45 protein in herpes simplex virus entry via low $\mathrm{pH}$-dependent endocytosis and its relationship to the conformation and function of glycoprotein B. Virus Res. 2010;149(1):115-8.

70. Komala Sari T, Pritchard SM, Cunha CW, Wudiri GA, Laws El, Aguilar HC, et al. Contributions of herpes simplex virus type 1 envelope proteins to entry by endocytosis. J Virol. 2013;87(24):13922-26. doi:10.1128/JVI.02500-13.

71. Eisenberg RJ, Atanasiu D, Cairns TM, Gallagher JR, Krummenacher C, Cohen $\mathrm{GH}$. Herpes virus fusion and entry: a story with many characters. Viruses. 2012;4(5):800-32. doi:10.3390/v4050800.

72. Campadelli-Fiume G, Menotti L, Avitabile E, Gianni T. Viral and cellular contributions to herpes simplex virus entry into the cell. Curr Opin Virol. 2012;2(1):28-36. doi:10.1016/j.coviro.2011.12.001.

73. Hadigal S, Shukla D. Exploiting herpes simplex virus entry for novel therapeutics. Viruses. 2013;5(6):1447-65. doi:10.3390/v5061447.

74. Delboy MG, Siekavizza-Robles CR, Nicola AV. Herpes simplex virus tegument ICPO is capsid associated, and its E3 ubiquitin ligase domain is important for incorporation into virions. J Virol. 2010;84(3):1637-40. doi:10.1128/JVI.02041-09.

75. Delboy MG, Patterson JL, Hollander AM, Nicola AV. Nectin-2-mediated entry of a syncytial strain of herpes simplex virus via $\mathrm{pH}$-independent fusion with the plasma membrane of Chinese hamster ovary cells. Virol J. 2006;3(1):105.

76. Yu X, Liu L, Wu L, Wang L, Dong C, Li W, et al. Herpes simplex virus type 1 tegument protein VP22 is capable of modulating the transcription of viral TK and gC genes via interaction with viral ICP0. Biochimie. 2010;92(8):1024-30. doi:10.1016/j.biochi.2010.04.025.

\section{Submit your next manuscript to BioMed Central and take full advantage of:}

- Convenient online submission

- Thorough peer review

- No space constraints or color figure charges

- Immediate publication on acceptance

- Inclusion in PubMed, CAS, Scopus and Google Scholar

- Research which is freely available for redistribution

Submit your manuscript at www.biomedcentral.com/submit 